\title{
Narrative role of vitamin D receptor with osteoporosis and obesity in a sample of Egyptian females: a pilot study
}

Nayera E. Hassan ${ }^{1}$, Sahar A. El-Masry ${ }^{1 *}$ D, Waheba Ahmed Zarouk², Ghada Nour Eldeen², Rehab M. Mosaad², Mahmoud A. S. Afify ${ }^{1}$, Manal M. Aly ${ }^{1}$ and Aya Khalii ${ }^{1}$

\begin{abstract}
Background: Vitamin D receptor (VDR) is known as one of the cellular regulators for several metabolic pathways indicating its pivotal role in the pathological pathway of numerous diseases. Considering the high frequency of osteoporosis and obesity among women, the current study aimed to explore the prospective assembly of the most frequent two VDR loci, single nucleotide polymorphism SNPs rs731236 (Taql) and rs7975232 (Apal) with a genetic predisposition to osteoporosis (skeletal) and obesity (chronic non-skeletal disorders), in Egyptian women. This was a cross-sectional study, including 97 Egyptian females (25-65 years), randomly chosen, from all employees and workers of the National Research Centre, Egypt. Anthropometric measurements (weight, height, BMI), dual-energy $X$-ray absorptiometry (DEXA), and molecular genetic analysis were done.
\end{abstract}

Results: The variation of Apal genotype between the normal and osteoporotic groups denotes a remarkable association of the homozygote Apal genotype with osteoporosis risk. Among the normal weight group, bone mineral density (BMD) was significantly associated with TaqI VDR gene polymorphism as the presence of the heterozygote genotype was accompanied with higher BMD while the homozygote one was detected with lower BMD. Also, Taql VDR gene polymorphism was significantly associated with BMI when participants were divided according to the presence of osteoporosis; increased BMI was expressed in the non-osteoporotic women group carrying the homozygote genotype of Taq I VDR gene while the presence of the heterozygote genotype (Taql) in the osteoporotic group was associated with increased BMI.

Conclusions: The heterozygote Taql genotype is protective against the osteoporosis phenotype and accompanied with increased BMI among osteoporotic women, while the homozygote Apal genotype has a significant association with osteoporosis risk.

Keywords: Vitamin D receptor polymorphism, Taql genotype, Apal genotype, Osteoporosis, Obesity, Egyptian females

\section{Background}

Osteoporosis and obesity are worldwide health problems and greatly affecting public health, being often associated with high morbidity and mortality leading to reduced quality of life and increased economic cost [1].

\footnotetext{
* Correspondence: masrysa@yahoo.com

'Biological Anthropology Department, Medical Research Division, National

Research Centre, 33 El-Bohooth St., Dokki, Cairo, Giza 12622, Egypt

Full list of author information is available at the end of the article
}

Worldwide, there is a difference in gender as one-third of women above the age of 50 years were exposed to osteoporotic fractures in relation to one-fifth of men of the same age group [2]. The prevalence of obesity worldwide indicates a pandemic; the health and demographic survey enrolled by the Health Ministry in Egypt indicates that around $46.3 \%$ of females are obese [3]. The etiology of both diseases has been supposed to arise from dysregulation of bone marrow mesenchymal stromal cells 
which are considered as a common precursor cell for both osteoblasts and adipocytes [4].

Data originating from twin studies has reported that genetic factors represent up to $85 \%$ of diversity in bone mass [5] and the coincidence for fat mass among monozygotic (MZ) twins has been denoted to range from 70 to $90 \%$, while in dizygotic (DZ) twins it is $35-45 \%$ [6].

Vitamin $\mathrm{D}$ metabolic functions occur through the binding of the active form of vitamin $\mathrm{D}$ receptor (VDR), 1, 25-dihydroxy-vitamin $\mathrm{D}(1,25(\mathrm{OH}) 2 \mathrm{D})$, to it. Then, the retinoic acid receptor (RXR) joins this complex, producing ultimately heterodimers that act on vitamin D response elements targeting gene promotor regions. A cascade of transcriptional regulations affecting target genes occurs. VDRs exist nearly in all human tissues including adipose tissue. They are mediating the function of vitamin D and so are essential for epigenome and expression of more than 1000 genes [7].

The human $V D R$ gene is localized on chromosome 12q13.1 which spans $\sim 75 \mathrm{~kb}$ genomic DNA and is presented with 11 exons [8]. Several VDR genetic polymorphisms are reported. The $3^{\prime}$ end region is part of the ligand-binding domain of the VDR. The reported polymorphisms such as that of ApaI and TaqI, which are located at the $3^{\prime}$ untranslated region (3'UTR) of the VDR gene, are the most prevalent and extensively studied genetic markers in relation to bone mineral density (BMD) variations in adult females as it influences the mRNA stability and VDR expression [9]. The structural protein variations secondary to ApaI and TaqI polymorphisms may lead to alternation of the binding specificity of vitamin D. Mutations in functional regions of the $V D R$ gene affect the metabolism of minerals-especially calcium - and therefore bone density [10]. Variations in VDR genetic alleles have been demonstrated to be associated with metabolic syndrome (MS) and its components including anthropometric parameters related to obesity. Although the genetic background of obesity is complex, recently, it was evidenced that functional polymorphisms of certain genes might affect the whole interindividual susceptibility to obesity $[11,12]$.

On contrary, some studies have reported that there is no association between VDR gene polymorphisms and the risk for MS development [13-15]. This debate remains unclear and requires further large-scale studies.

evidence that; obesity and osteoporosis share some common genetic determinations and the fact that the VDR is widely distributed, is controlling genes related to bone metabolism, chronic diseases, and inflammation. Consequently, it is fundamental to verify, characterize, and correlate the occurrence of such genetic variations of the VDRs. This will propose a personalized clinical approach to prohibit or at least postpone the development of these chronic diseases and subsequent complications. From this point of view, this study was conducted to evaluate the genetic association of selected polymorphic variants within the $V D R$ gene, particularly ApaI (rs7975232) and TaqI (rs731236), in obesity development and osteoporotic risk, among a sample of Egyptian females, a country where obesity is reaching endemic proportions.

\section{Methods}

This was a cross-sectional study, which included 97 Egyptian women. Their ages ranged between 25 and 65 years with a mean age of $48.85 \pm 9.88$ years. They were recruited and randomly chosen, from all employees and workers, of all categories, of the "National Research Centre", Egypt. All participated women were free from any chronic disease or under long-term medications. A written informed consent was obtained from all participants after being informed about the purpose of the study. This research paper was derived from a crosssectional survey of a project funded by "National Research Centre", Egypt, 2016-2019 entitled "Bone mass among Overweight and Obese Women: Mechanism and Intervention." "National Research Centre", with an approval obtained from the Ethics Committee of "National Research Centre" (registration number is 16/127).

For each participant woman, anthropometric measurements, dual-energy X-ray absorptiometry (DEXA) measurements, and molecular genetic analysis were done.

\section{Anthropometric measurements}

Body weight and height were measured, following the recommendations of the "International Biological Program" [16]. Body weight (Wt) was determined to the nearest $0.01 \mathrm{~kg}$ using a Seca Scale Balance, with the woman wearing minimal clothes and with no shoes. Body height $(\mathrm{Ht})$ was measured to the nearest $0.1 \mathrm{~cm}$ using a Holtain portable anthropometer. Body mass index (BMI) was calculated: [BMI: weight (in kilograms) divided by height (in meters squared)]. The participant women were classified according to their BMI into 2 groups: 31 women with normal BMI $\left(<25 \mathrm{~kg} / \mathrm{m}^{2}\right)$ and 66 overweight/obese women $\left(\geq 25 \mathrm{~kg} / \mathrm{m}^{2}\right)$.

\section{DEXA measurements}

Both bone mineral density "BMD" $\left(\mathrm{gm} / \mathrm{cm}^{2}\right)$ and BMD $T$ score at the neck of the femur were measured using dual-energy DEXA (DEXA Norland XR-46 version 3.9.6/ 2.3.1, USA). A full body DEXA scan, based on the woman's age, weight, and height, was performed with the participant keeping the precise distance between her arms and legs according to the machine instruction manual. A well-qualified operator executed and evaluated all analyses using the same protocol for all assessments. According to the WHO diagnostic criteria [17] 
depending on BMD $T$ score at any of the recommended sites (lumbar spine or femoral neck), the women were classified into 3 groups: women with healthy bone ( > -1 ), osteopenia (between -1 and $>-2.5$ ), and osteoporosis $(<-2.5)$ [18]. After that, BMD $T$ score -1 was taken to group the participating women to a non-osteoporotic or osteoporotic group.

\section{Molecular genetic analysis Genomic DNA extraction}

Genomic DNA was extracted using Qiagen QIAamp DNA Blood Mini Kit from whole blood samples according to the manufacturer's protocol. The concentration of genomic DNA was determined by quantitative method, based on optical density measurement using NanoDrop UV/V (Thermo Scientific, UK). The purity of DNA was determined by calculating the ratio of absorbance at 260 $\mathrm{nm}$ to absorbance at $280 \mathrm{~nm}\left(A_{260} / A_{280}\right)$. Pure DNA should have an $A_{260} / A_{280}$ ratio of $1.7-1.9$, respectively.

\section{VDR gene polymorphism genotyping by PCR-restriction fragment length polymorphism (RFLP)}

The ApaI and TaqI polymorphic sites of VDR were considered. The targeted SNP was amplified by conventional polymerase chain reaction (PCR) and followed by restriction digestion. The VDR genotype of each subject was identified according to the digestion pattern and alleles.

TaqI polymorphism $P C R$ amplification: PCR reaction was carried out in $25-\mu \mathrm{L}$ reaction mixture containing 1.5 $\mathrm{mM} \mathrm{MgCl} 2,0.2 \mathrm{mM} \mathrm{dNTP}$, and 10 pmoles of each primer sequences F: 5' -CAG AGC ATG GAC AGG GAG CAA-3' and R: 5'-CAC TTC GAG CAC AAG GGG CGT TAG C-3' as described previously by Mohamed and El-Askary [19], $0.5 \mathrm{U}$ of Taq DNA polymerase, and 200ng of genomic DNA. PCR conditioning was as follows: initial denaturation for $5 \mathrm{~min}$ at $95^{\circ} \mathrm{C}, 30$ cycles of
30 s at $94^{\circ} \mathrm{C}$, annealing for $45 \mathrm{~s}$ at $57^{\circ} \mathrm{C}$, extension for $60 \mathrm{~s}$ at $72^{\circ} \mathrm{C}$, and a final extension for $5 \mathrm{~min}$ at $72{ }^{\circ} \mathrm{C}$.

ApaI polymorphism $P C R$ amplification: $\mathrm{PCR}$ reaction was carried out in $25-\mu \mathrm{L}$ reaction mixture containing 1.5 $\mathrm{mM} \mathrm{MgCl} 2,0.2 \mathrm{mM} \mathrm{dNTP}$, and 10 pmoles of each primer sequences F: 5'-CAA CCA AGA CTA CAA GTA CCG CGT CAG TGA-3' and R: 5'-CAC TTC GAG CAC AAG GGG CGT TAG C-3' as described previously by Mohamed and El-Askary [19], $0.5 \mathrm{U}$ of Taq DNA polymerase, and 200ng of genomic DNA. PCR conditioning was as follows: initial denaturation for 5 min at $95^{\circ} \mathrm{C}, 30$ cycles of $30 \mathrm{~s}$ at $94^{\circ} \mathrm{C}$, annealing for $45 \mathrm{~s}$ at $55^{\circ} \mathrm{C}$, extension for $60 \mathrm{~s}$ at $72^{\circ} \mathrm{C}$, and a final extension for $10 \mathrm{~min}$ at $72{ }^{\circ} \mathrm{C}$.

Post-PCR-RFLP: The resulting DNA fragments were subjected to restriction digestion using respective enzymes ApaI and Taq-I (Promega, Madison, USA, $10 \mathrm{U} /$ $\mathrm{ml}$ ). The Eppendorf tubes for RFLP were prepared as follows: $10 \mu \mathrm{l}$ of PCR product; $16.3 \mu \mathrm{l}$ of sterile, deionized water; $0.2 \mu \mathrm{l}$ of 100X BSA; and $2 \mu \mathrm{l}$ of 10X RE Buffer, and mixed by pipetting. Finally, 10 units of each of the respective restriction enzymes were added. The tubes were incubated $\left(2 \mathrm{~h}\right.$ at $37^{\circ} \mathrm{C}$ for ApaI and Taq I polymorphisms) and heat inactivated for $15 \mathrm{~min}$ at $80^{\circ} \mathrm{C}$. The genotypes were resolved on $2 \%(\mathrm{w} / \mathrm{v})$ agarose gels.

3-Genotyping: The genotypes were resolved on $2 \%(\mathrm{w} /$ v) agarose gels. ApaI polymorphism genotyping for wild type homozygosis fragment (AA) at 740-bp mutant homozygosis fragments (aa) at 530 and $210 \mathrm{bp}$ and heterozygosis produces fragment (Aa) of 740, 530, and $210 \mathrm{bp}$. In the presence of A-allele, there was no restriction enzyme cleavage site and a product of $740 \mathrm{bp}$ was obtained. In subjects carrying "a-allele," the cleavage products of 530 and 210 bp were detected. Alleles "A" and "a" were assigned based on the presence of a 740-bp (uncleaved) fragment and the 530-bp and 210-bp (cleaved) fragments, respectively (Fig. 1). TaqI polymorphism genotyping for wild type homozygosis

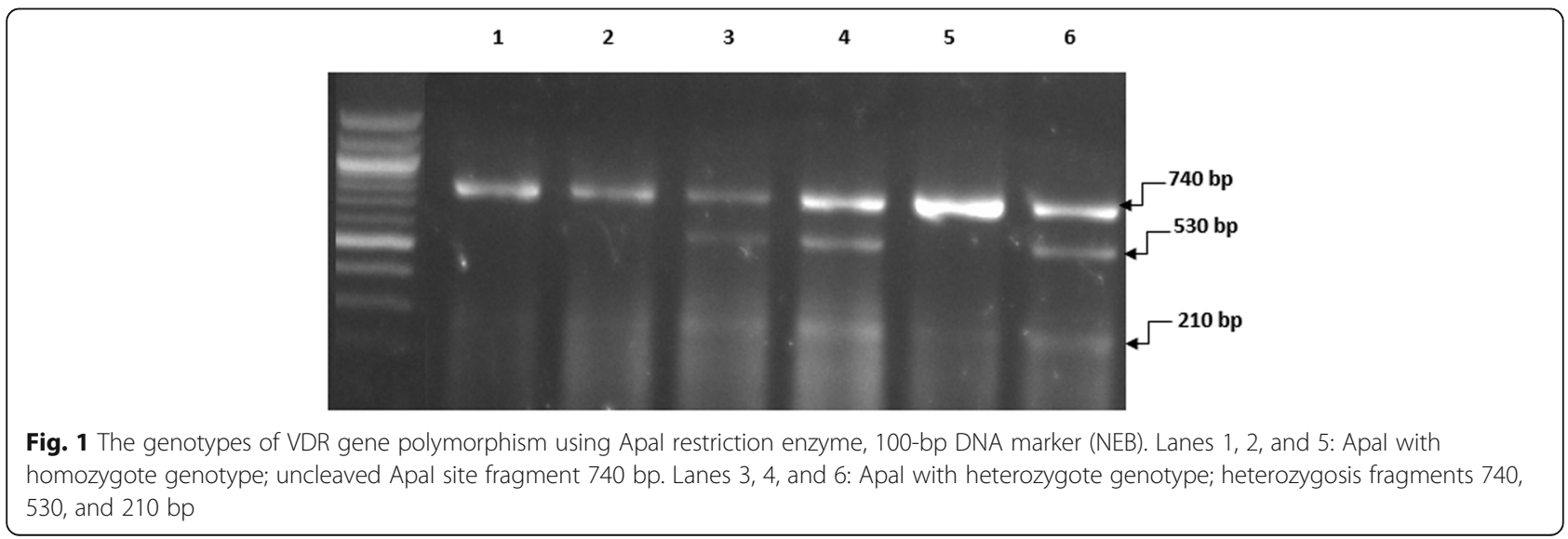




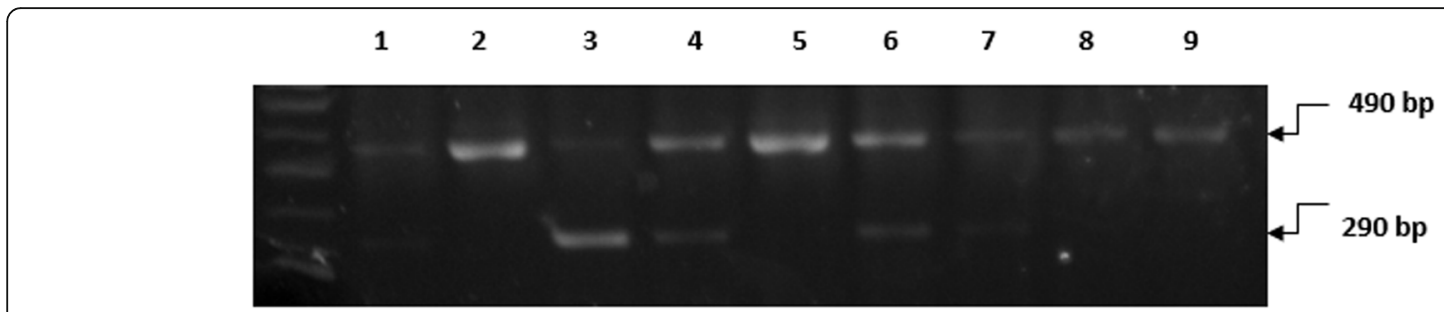

Fig. 2 PCR-RFLP analysis of the VDR gene polymorphism, using Taql restriction enzyme 100-bp DNA marker (NEB). Lanes 1, 3, 4, 6, and 7: heterozygous genotype; fragments; 495, 290, and 205 bp (undetected). Lanes 2, 5, 8, and 9: wild type homozygote

produces fragment (TT) at $495 \mathrm{bp}$ while heterozygosis produces fragments $(\mathrm{Tt})$ at 495,290 , and $205 \mathrm{bp}$. The allele "T" was associated with the presence of a 495-bp fragment, while allele " $C$ " was assigned in the presence of 290-bp and 205-bp fragments (Fig. 2).

\section{Statistical analysis}

Data were analyzed using the Statistical Package for Social Sciences (SPSS/Windows version 16, SPSS Inc., Chicago, IL, USA). The normality of data was tested using the Kolmogorov-Smirnov test. The data of DEXA, weight, and BMI were not normally distributed. So, nonparametric tests were used.

The 97 participant women were classified twice into 2 groups: first according to their BMI (31 normal weight and 66 overweight/obese) and second according to their BMD $T$ score (23 osteoporotic and 74 nonosteoporotic). The parametric data were expressed as mean $\pm \mathrm{SD}$, where the qualitative ones were expressed as number and percentage (\%). The various parametric variables of the different groups were analyzed and compared using the Mann-Whitney test for independent groups, while the frequency distribution of the vitamin $D$ receptors among different groups (non-parametric data) were compared using the chi-square test. $P<0.05$ was regarded as statistically significant for all tests.

\section{Results}

Frequency distribution of VDR gene polymorphisms (TaqI and ApaI) among non-osteoporotic and osteoporotic groups (Table 1) revealed that ApaI polymorphism was significantly associated with BMD $(P=0.012)$. The homozygote ApaI genotype was the most abundant among osteoporotic women (95.7\%), while the heterozygote one was more frequent among non-osteoporotic women (35.1\%). Meanwhile, the frequency distribution of VDR (ApaI and TaqI) genes among overweight/obese cases and the normal weight group (Table 2) showed insignificant differences in the distribution of VDR polymorphisms.

Comparisons of the means \pm SD of BMI and BMD at the femur neck between genotypes of Taq I and ApaI VDR gene polymorphisms among different groups are presented in Tables 3 and 4. Among the normal weight women (Table 3), the Taq I genotype of VDR had a significant effect on BMD value and osteoporotic risk, as the heterozygote genotype of TaqI VDR gene polymorphism had higher BMD than the homozygote one in the same group $(P=0.000)$.

When groups were divided according to the presence or absence of osteoporosis (osteoporosis risk) (Table 4), BMI values differ by VDR gene polymorphisms in the case of TaqI and this difference was statistically significant $(P=0.032)$. BMI was increased among women carrying the homozygote genotype of Taq I VDR gene in the non-osteoporotic group, while increased BMI was associated with the heterozygote Taq I genotype in the osteoporotic group.

\section{Discussion}

The abundant distribution of VDRs in skeletal and nonskeletal tissues and its existence in several cellular

Table 1 Frequency distribution of Taql and Apal genotypes among non-osteoporotic and osteoporotic groups

\begin{tabular}{|c|c|c|c|c|c|c|}
\hline \multirow[t]{2}{*}{ Variables } & & \multicolumn{2}{|c|}{ Non-osteoporotic $(N=74)$} & \multicolumn{2}{|c|}{ Osteoporotic $(N=23)$} & \multirow[t]{2}{*}{ Chi-square } \\
\hline & & $N$ & $\%$ & $N$ & $\%$ & \\
\hline \multicolumn{7}{|c|}{ Vit. D receptor } \\
\hline \multirow[t]{2}{*}{ Taq1 } & Homo & 42 & 56.8 & 18 & 78.3 & 0.064 \\
\hline & Hetero & 32 & 43.2 & 5 & 21.7 & \\
\hline \multirow[t]{3}{*}{ Apa1 } & Homo & 47 & 63.5 & 22 & 95.7 & $0.012^{*}$ \\
\hline & Hetero & 26 & 35.1 & 1 & 4.3 & \\
\hline & Mutant & 1 & 1.4 & 0 & 0 & \\
\hline
\end{tabular}


Table 2 Frequency distribution of Taql and Apal genotypes among overweight/obese and normal weight groups

\begin{tabular}{|c|c|c|c|c|c|c|}
\hline \multirow[t]{2}{*}{ Variables } & & \multicolumn{2}{|c|}{ Overweight/obese $(N=66)$} & \multicolumn{2}{|c|}{ Normal weight $(N=31)$} & \multirow[t]{2}{*}{ Chi-square } \\
\hline & & $\bar{N}$ & $\%$ & $\bar{N}$ & $\%$ & \\
\hline \multicolumn{7}{|c|}{ Vit. D receptor } \\
\hline \multirow[t]{2}{*}{ Taq1 } & Homo & 43 & 65.2 & 17 & 54.8 & 0.330 \\
\hline & Hetero & 23 & 34.8 & 14 & 45.2 & \\
\hline \multirow[t]{3}{*}{ Apa1 } & Homo & 44 & 66.7 & 25 & 80.6 & 0.329 \\
\hline & Hetero & 21 & 31.8 & 6 & 19.4 & \\
\hline & Mutant & 1 & 1.5 & 0 & 0 & \\
\hline
\end{tabular}

cascades indicates its crucial role in the pathophysiology of many diseases [20, 21]. Numerous studies investigated the association between $V D R$ variants (ApaI and TaqI) and bone disorders and disparate results were detected. The current study found a significant association between ApaI VDR genotypes and osteoporosis in Egyptian women. This finding was supported and pooled in a large meta-analysis performed by Zhang et al. [22] who reported that there were significant correlations between VDR ApaI and postmenopausal osteoporosis susceptibility in the Caucasian populations and indicating that postmenopausal females having mutant allele of VDR ApaI might have less susceptibility to osteoporosis compared to those with wild genotype. Also, our results identified higher BMD among the normal weight women group carrying the heterozygote genotype of the VDR TaqI polymorphism than those with the homozygote one and this difference is statistically significant. In agreement with our results, in Belarusian osteoporotic postmenopausal women, both ApaI and TaqI genetic variations were found to be introducing factors of osteoporosis [23].

On contrary, a meta-analysis study by Shen et al. [24], of total 6500 osteoporotic women, showed that no association was found among the ApaI and TaqI polymorphisms and the prevalence of bone fracture. Also, Wang et al. [25] and Zhang et al. [22] conducted meta-analyses of 18 studies of VDR TaqI polymorphism and reported no significant relationship between TaqI polymorphism and osteoporosis incidence, while in Yadav et al. [26] meta-analysis, a total of 65 (14929 samples), 31 (7697 samples), 18 (3617 samples), and 26 (5353 samples) were studied. The authors found that the recessive model of TaqI polymorphism is associated with osteoporosis in the Caucasian population. The other polymorphism ApaI has no significant effect in low bone density. The prevalence of various VDR gene natural variants varies in numerous ethnic/regional populations. Due to this, the influence of these variations might vary from ethnic group to another. In addition, they provided that various gene to gene interactions and the epigenetic role of the environment should also be extensively studied in the future, as it could explain the genetics of osteoporosis [26]. Sakamoto et al. [27] study on 499 Japanese women showed that the VDR TaqI genotypes are significantly associated with bone mass in young Japanese women. Among them, the VDR ApaI heterozygote genotype is associated with increased bone mass concomitant with higher calcium intake.

In the current study, a significant association between TaqI VDR SNPs and obesity phenotype was found when

Table 3 Comparisons of means \pm SD of BMI and BMD between different genotypes of Taql and Apal VDR among overweight/ obese and normal weight women

\begin{tabular}{|c|c|c|c|c|c|c|c|c|c|c|}
\hline \multirow[t]{4}{*}{ Variables } & \multicolumn{5}{|l|}{ Taq1 } & \multicolumn{5}{|l|}{ Apa1 } \\
\hline & \multicolumn{10}{|c|}{ Overweight/obese $(N=66)$} \\
\hline & \multicolumn{2}{|c|}{$\mathrm{HOMO}(N=43)$} & \multicolumn{2}{|c|}{ Hetero $(N=23)$} & \multirow[t]{2}{*}{$P$} & \multicolumn{2}{|c|}{$\mathrm{HOMO}(N=44)$} & \multicolumn{2}{|c|}{ Hetero $(N=22)$} & $P$ \\
\hline & Mean & $\pm \mathrm{SD}$ & Mean & $\pm \mathrm{SD}$ & & Mean & $\pm \mathrm{SD}$ & Mean & $\pm \mathrm{SD}$ & \\
\hline BMI & 34.44 & 5.46 & 36.56 & 9.13 & 0.652 & 35.19 & 6.96 & 35.56 & 7.05 & 0.888 \\
\hline \multirow[t]{4}{*}{ BMD $T$ score at the femur neck } & -1.40 & 1.16 & -1.41 & 1.45 & 0.928 & -1.38 & 1.36 & -1.41 & 1.03 & 0.968 \\
\hline & \multicolumn{10}{|c|}{ Normal weight women $(N=31)$} \\
\hline & \multicolumn{2}{|c|}{$\mathrm{HOMO}(N=17)$} & \multicolumn{2}{|c|}{ Hetero $(N=14)$} & $P$ & \multicolumn{2}{|c|}{$\mathrm{HOMO}(N=25)$} & \multicolumn{2}{|c|}{ Hetero $(N=6)$} & $P$ \\
\hline & Mean & $+S D$ & Mean & $+\mathrm{SD}$ & & Mean & $\pm \mathrm{SD}$ & Mean & $\pm \mathrm{SD}$ & \\
\hline BMl & 22.46 & 1.74 & 22.68 & 1.99 & 0.597 & 22.29 & 1.95 & 23.66 & 0.15 & 0.105 \\
\hline BMD $T$ score at the femur neck & -2.90 & 0.47 & -1.96 & 0.25 & $0.000^{* *}$ & -2.53 & 0.66 & -2.23 & 0.17 & 0.314 \\
\hline
\end{tabular}


Table 4 Comparisons of means \pm SD of BMI and BMD between different genotypes of Taql and Apal VDR in non-osteoporotic and osteoporotic women

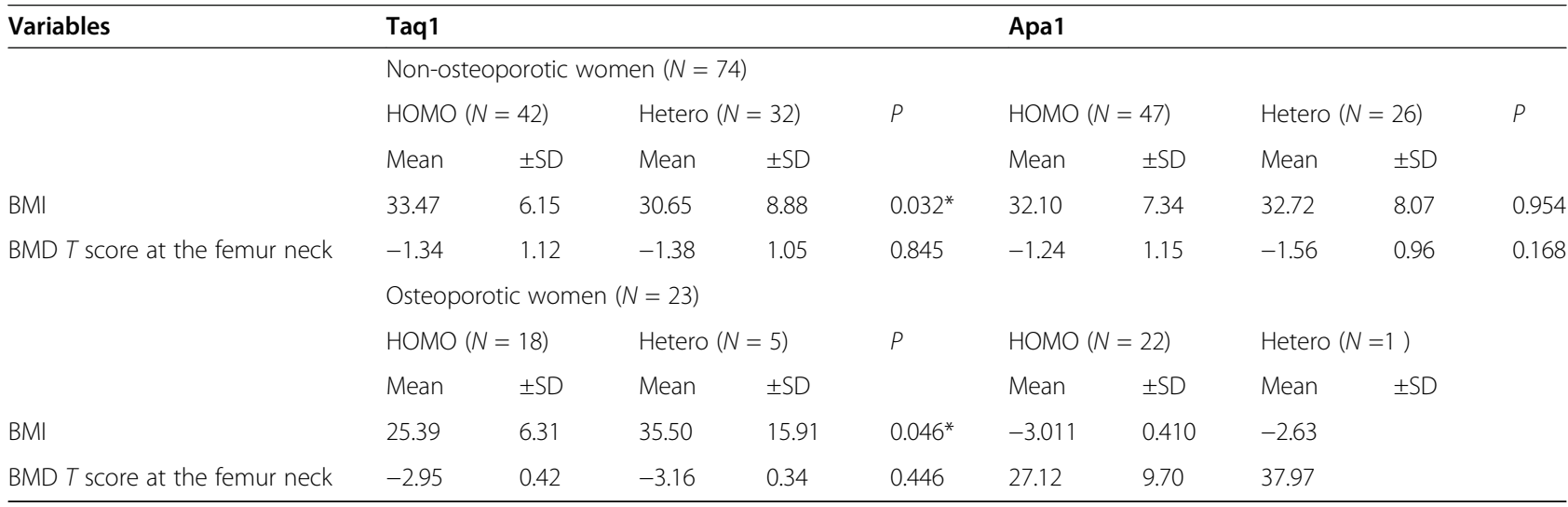

N.B. $B M I$ body mass index, $B M D$ bone mineral density; ${ }^{*} P<0.05=$ significant differences

studied groups were subdivided according to the presence of osteoporosis. Chen et al. [28] performed metaanalysis studies, including 1188 obese patients and 1657 healthy controls, to study the relationship between VDR polymorphisms and the incidence of obesity based on several case-control studies. Among them, the presence of the VDR ApaI natural variant with obesity susceptibility was investigated in 3 studies $[11,29,30]$ and the TaqI polymorphism by Yiannis et al. [31], Fan et al. [29], Al Hazmi et al. [11], and Bienertová-Vašků et al. [30]. This meta-study reported that the $\mathrm{T}$ allele of TaqI could have a preservative role it could not find in the relationship between ApaI polymorphism and the incidence of obesity. Ruiz-Ojeda and his colleagues [32] hypothesized that allelic variations in the $V D R$ gene might be potential participators in obesity pathophysiology through alternating adipocyte function and increasing adipocyte inflammation association. Some other studies denoted no association between VDR genetic variations and the susceptibility for MS development and its components including different elements of anthropometry related to obesity [13, 14]. In parallel, Karonova et al. [33] study found no significant relationship between VDR SNPs, rs7975232 (ApaI) and rs731236 (TaqI), and anthropometric of MS risk. Nam et al. [34] study on 506 Korean patients supports the association of VDR genetic variants and obesity risk.

In summary, the current study investigated the distribution of the VDR gene TaqI and ApaI variants' effect on BMI and BMD among osteoporotic and nonosteoporotic women. A statistically significant difference was detected when the polymorphism genotype frequency was analyzed with regard to Taq I polymorphism only. BMI was significantly higher in non-osteoporotic women with the homozygote genotype than those with the heterozygote one, while in contrast the presence of this latter genotype (heterozygote TaqI) was accompanied with increased BMI in osteoporotic women. These observations are consistent with the view that phenotypes of various diseases may be the yields of interlinkage between genotypes and several environmental factors which may mask the genetic effects.

\section{Conclusions}

The heterozygote TaqI genotype seems to be protective against the osteoporosis phenotype and it was accompanied with increased BMI among osteoporotic women, while the homozygote ApaI genotype has a significant association with osteoporosis risk. These polymorphisms may be considered useful markers for the screening of osteoporosis and obesity in certain ethnicities and may be potential targets for genetic therapy.

\section{Limitations}

One of the main limitations in our work is the lack of control of confounding factors such as smoking. Second is the small sample size enrolled in the current study of Egyptian females; so, future studies in larger scale should focus on multiple haplotypes, to clarify the possible overall impacts of common VDR polymorphisms.

\section{Abbreviations \\ 1, 25(OH) 2D: 1, 25-Dihydroxy-vitamin D; BMD: Bone mineral density; BMI: Body mass index; DEXA: Dual-energy X-ray absorptiometry; DZ twins: Dizygotic twins; Ht: Body height; MS: Metabolic syndrome; MZ twins: Monozygotic twins; PCR: Polymerase chain reaction; SD: Standard deviation; SNPS: Single nucleotide polymorphisms; SPSS: Statistical Package for Social Sciences; RFLP: Restriction fragment length polymorphism; RXR: Retinoic acid receptor; Vit. D: Vitamin D; VDR: Vitamin D receptor; 3' UTR: 3' Untranslated region; WC: Waist circumference; Wt: Body weight; WHO: World Health Organization}

\section{Acknowledgements}

We would like to acknowledge our institute "National Research Centre, Egypt"; without its fund, this study could not be done. The authors are also grateful to everybody who participated in this study, the employers of our institute who were the participants of this study, and the doctors who 
participated in the collection of the data. Without their help, this study could not have been completed.

\begin{abstract}
Authors' contributions
$\mathrm{NE}$ is the principal investigator (P.I.) and designed the project and the study as well revised every step of the project and gave conceptual advice; SA is the co-PI of the project from which this data was derived, performed the statistical analysis, and shared in the tabulation of the data and publication process; WA wrote the draft of the manuscript; Gh.N and RM were responsible about the genetic analysis; A.Kh performed the DEXA scan and the anthropology measurements; MM and MA had taken anthropology measurements. All authors read and have approved the submitted version. They have agreed both to be personally accountable for the author's own contributions and to ensure that questions related to the accuracy or integrity of any part of the work, even ones in which the author was not personally involved, are appropriately investigated, resolved, and the resolution documented in the literature.
\end{abstract}

\section{Funding}

This research paper was derived from a project funded by the National Research Centre (NRC), Egypt, 2016-2019 entitled "Bone mass among Overweight and Obese Women: Mechanism and Intervention." (11th Research Plan of the NRC), as part of our jobs.

\section{Availability of data and materials}

The datasets used and/or analyzed during the current study are available from the corresponding author on reasonable request, after taking the permission of our institute "National Research Centre."

\section{Declarations}

\section{Ethics approval and consent to participate}

A written informed consent was obtained from all participants after being informed about the purpose of the study. This research paper was derived from a cross-sectional survey of a project funded by the National Research Centre (NRC), Egypt, 2016-2019 entitled "Bone mass among Overweight and Obese Women: Mechanism and Intervention." (11th Research Plan of the NRC), with an approval obtained from the Ethics Committee of NRC (registration number is $16 / 127$ ).

\section{Consent for publication}

Not applicable.

\section{Competing interests}

The authors declare that they have no competing interests.

\section{Author details}

${ }^{1}$ Biological Anthropology Department, Medical Research Division, National Research Centre, 33 El-Bohooth St., Dokki, Cairo, Giza 12622, Egypt. ${ }^{2}$ Molecular Genetics and Enzymology Department, Human Genetics and Genome Division, National Research Centre, Cairo, Egypt.

Received: 24 March 2021 Accepted: 26 July 2021

Published online: 05 August 2021

\section{References}

1. Greco EA, Lenzi A, Migliaccio S (2015) The obesity of bone. Ther Adv Endocrinol Metab. 6(6):273-286

2. Trevisan C, Alessi A, Girotti G, Zanforlini BM, Bertocco A, Mazzochin M, Zoccarato F, Piovesan F, Dianin M, Giannini S, Manzato E, Sergi G (2020) The impact of smoking on bone metabolism, bone mineral density and vertebral fractures in postmenopausal women. J Clin Densitom 23(3):381389

3. El-Zanaty and Associates [Egypt], International I (2015) Egypt demographic and health survey 2014. Ministry of Health and Population and ICF International, Cairo and Rockville

4. Horowitz MC, Lorenzo JA (2004) The origin of osteoclasts. Curr Opin Rheumatol. 16:464-468

5. Nakamura T (2004) WHO diagnostic criteria for osteoporosis and trends in Europe and USA. Nihon Rinsho 62(Suppl 2):235-239
6. Lyon HN, Hirschhorn JN (2005) Genetics of common forms of obesity: a brief overview. Am J Clin Nutr 82(1):215S-217S. https://doi.org/10.1093/ajcn/ 82.1.215S

7. Carlberg C (2019) Nutrigenomics of vitamin D. Nutrients 11(3):676. https:// doi.org/10.3390/nu11030676

8. Hewison M, Zehnder D, Chakraverty R, Adams JS (2004) Vitamin D and barrier function: a novel role for extra-renal 1a-hydroxylase. Mol Cell Endocrinol 215(1-2):31-38. https://doi.org/10.1016/j.mce.2003.11.017

9. Uitterlinden AG, Fang Y, Van Meurs JB, Pols HA, Van Leeuwen JP (2004) Genetics and biology of vitamin D receptor polymorphisms. Gene. 338(2): 143-156. https://doi.org/10.1016/j.gene.2004.05.014

10. Banjabi AA, Al-Ghafari AB, Kumosani TA, Kannan K, Fallatah SM (2020) Genetic influence of vitamin $D$ receptor gene polymorphisms on osteoporosis risk. Int J Health Sci (Qassim) 14(4):22-28

11. Al-Hazmi AS, Al-Mehmadi MM, Al-Bogami SM et al (2017) Vitamin D receptor gene polymorphisms as a risk factor for obesity in Saudi men. Electron Physician 9(10):5427-5433. https://doi.org/10.19082/5427

12. Man H, Yu Z, Dan L et al (2018) Association between $-174 G>C$ polymorphism in the IL-6 promoter region and the risk of obesity: a metaanalysis. Medicine. 97:e11773

13. Shab-Bidar S, Neyestani TR, Djazayery A (2017) Vitamin D receptor gene polymorphisms, metabolic syndrome, and type 2 diabetes in Iranian subjects: no association with observed SNPs. Int J Vitam Nutr Res 10:1-10

14. Hasan HA, AbuOdeh RO, Muda WAMBW, Mohamed HJBJ, Samsudin AR (2017) Association of vitamin D receptor gene polymorphisms with metabolic syndrome and its components among adult Arabs from the United Arab Emirates. Diabetes Metab Syndr 11(Suppl. 2):531-537

15. Correa-Rodriguez M, Carrillo-Avila JA, Schmidt-RioValle J, Gonzalez-Jimenez E, Vargas S, Martin J et al (2018) Genetic association analysis of vitamin D receptor gene polymorphisms and obesity-related phenotypes. Gene. 640: 51-56. https://doi.org/10.1016/j.gene.2017.10.029

16. Hiernaux J, Tanner JM (1969) Growth and physical studies. In: Weiner JS, Lourie SA (eds) Biology human. A guide to field methods. IBP. London, Blackwell Scientific Publications; 1969, Oxford

17. WHO Scientific Group on the Prevention and Management of Osteoporosis: Geneva, Switzerland (2003). Prevention and management of osteoporosis: report of a WHO scientific group. World Health Organization. Tech Rep Ser 2003:921:1-164. https://apps.who.int/iris/handle/10665/42841.

18. NIH Consensus Statement (2000). Osteoporosis prevention, diagnosis, and therapy. NIH Consens Statement 2000;17(1):1-45.

19. Mohamed S, El-Askary A (2017) Vitamin D receptor gene polymorphism among Egyptian obese children. Asian J Clin Nutr 9:24-29

20. Pludowski P, Holick MF, Grant WB, Konstantynowicz J, Mascarenhas MR, Haq A (2018) Vitamin D supplementation guidelines. J Steroid BiochemMol Biol 175:125-135. https://doi.org/10.1016/j.jsbmb.2017.01.021

21. Sirajudeen S, Shah I, Al MA (2019) A narrative role of vitamin D and its receptor: with current evidence on the gastric tissues. Int J Mol Sci 20(15): 3832. https://doi.org/10.3390/ijms20153832

22. Zhang L, Yin X, Wang J, Xu D, Wang Y, Yang J, Tao Y, Zhang S, Feng X, Yan $C$ (2018) Associations between VDR gene polymorphisms and osteoporosis risk and bone mineral density in postmenopausal women: a systematic review and meta-analysis. Sci Rep 17(1):981

23. Marozik P, Mosse I, Alekna V, Rudenko E, Tamulaitienè M, Ramanau H et al (2013) Association between polymorphisms of VDR, COL1A1, and LCT genes and bone mineral density in Belarusian women with severe postmenopausal osteoporosis. Medicina (Kaunas) 49:177-184 [PubMed] [Google Scholar]

24. Shen H, Xie J, Lu H (2014) Vitamin D receptor gene and risk of fracture in postmenopausal women: a meta-analysis. Climacteric. 17(4):319-324. https://doi.org/10.3109/13697137.2013.856401

25. Wang QX, Zhao SM, Zhou YB, Zhang C (2018) Lack of association between vitamin D receptor genes Bsml as well as Apal polymorphisms and osteoporosis risk: a pooled analysis on Chinese individuals. Int J Rheum Dis 21(5):967-974. https://doi.org/10.1111/1756-185X.13282

26. Yadav U, Kumar P, Rai V (2020) Vitamin D receptor (VDR) gene Fokl, Bsml, Apal, and Taql polymorphisms and osteoporosis risk: a metaanalysis. Egypt J Med Human Genet 21(1):15. https://doi.org/10.1186/s43 042-020-00057-5

27. Sakamoto Y, Oono F, lida K, Wang PL, Tachi Y (2021) Relationship between vitamin D receptor gene polymorphisms (Bsml, Taql, Apal, and Fokl) and calcium intake on bone mass in young Japanese women. BMC Womens Health 21(1):76. https://doi.org/10.1186/s12905-021-01222-7 
28. Chen X, Wang W, Yanyan Wang Y, Han X, Gao L (2019) Vitamin D receptor polymorphisms associated with susceptibility to obesity: a meta-analysis. Med SciMonit 25:8297-8305

29. Fan HR, Lin LQ, Hao MA et al (2015) Association between vitamin D receptor gene polymorphism (Taql) and obesity in Chinese population. J Genet 94(3):473-478. https://doi.org/10.1007/s12041-015-0541-x

30. Bienertova-Vasku J, Zlamal F, Pohorala A, Mikes O, Goldbergova-Pavkova M, Novak J et al (2017) Allelic variants in vitamin D receptor gene are associated with adiposity measures in the central-European population. BMC Med Genet 18(1):90. https://doi.org/10.1186/s12881-017-0454-z

31. Yiannis V, Theologia S, Kalliopi K et al (2013) VDR Taql is associated with obesity in the Greek population. Gene. 512:237-239

32. Ruiz-Ojeda FJ, Anguita-Ruiz A, Leis R, Aguilera CM (2018) Genetic factors and molecular mechanisms of vitamin D and obesity relationship. Ann Nutr Metab 73:89-99

33. Karonova T, Grineva E, Belyaeva O, Bystrova A, Jude EB, Andreeva A, Kostareva A, Pludowski P (2018) Relationship between vitamin D status and vitamin $D$ receptor gene polymorphisms with markers of metabolic syndrome among adults. Front Endocrinol (Lausanne) 9:448

34. Nam SW, Choi J, Jeon HJ, Oh TK, Lee DH (2021) The associations between vitamin D receptor Bsml and Apal polymorphisms and obesity in Korean patients with type 2 diabetes mellitus. Diabetes Metab Syndr Obes 14:557-564

\section{Publisher's Note}

Springer Nature remains neutral with regard to jurisdictional claims in published maps and institutional affiliations.

\section{Submit your manuscript to a SpringerOpen ${ }^{\circ}$ journal and benefit from:}

- Convenient online submission

- Rigorous peer review

- Open access: articles freely available online

High visibility within the field

- Retaining the copyright to your article

Submit your next manuscript at $\boldsymbol{\nabla}$ springeropen.com 